\title{
Regional Value Chains and Industrialization of Sub-Saharan Africa
}

\author{
Desire Avom, Irene Tiako, Bernard Nguekeng \\ Laboratory LAREA, University of Yaoundé II, Yaounde, Cameroon \\ Email: davom99@gmail.com, tiakonga1@gmail.com,nguekengbernard@gmail.com
}

How to cite this paper: Avom, D., Tiako, I., \& Nguekeng, B. (2021). Regional Value Chains and Industrialization of Sub-Saharan Africa. Theoretical Economics Letters, 11, 1312-1327.

https://doi.org/10.4236/tel.2021.116082

Received: June 24, 2021

Accepted: December 27, 2021

Published: December 30, 2021

Copyright $\odot 2021$ by author(s) and Scientific Research Publishing Inc. This work is licensed under the Creative Commons Attribution International License (CC BY 4.0).

http://creativecommons.org/licenses/by/4.0/

(c) (i) Open Access

\begin{abstract}
The objective of this article is to determine the effects of integration into regional value chains on the industrialization of the countries of sub-Saharan Africa. To this end, after a review of the literature, we carried out an econometric analysis of panel data. The estimates with the GMM in the system have led to the following results: 1 ) integration into regional value chains participates in the industrialization of this sub-region. 2) Upstream integration contributes more to industrialization than downstream integration. In these circumstances, African leaders must encourage trade in intermediate products. For this to be effective, actions must be directed towards improving the level of infrastructure and the training of young Africans.
\end{abstract}

\section{Keywords}

Regional Value Chains, Industrialization, Sub-Saharan Africa, GMM in the System

\section{Introduction}

Over the past two decades, the growth of trade has been remarkable relative to that of total production, largely due to the proliferation of intermediate products that cross borders. The global export/output ratio increased from $20 \%$ to $25 \%$ between 1995 and 2009. Specifically, value-added exports increased from 15\% of global GDP in 1995 to about 20\% in 2009 (Ruta \& Saito, 2014). The main players in these exchanges are within the regional blocs of East Asia, Europe and North America (Baldwin, 2012). About $85 \%$ of value-added trade within global value chains takes place in and around these three platforms. While the other regions remain marginal, their share has increased from only $10 \%$ in 1995 to $15 \%$ in 2011. 
While sub-Saharan Africa has opened up considerably in recent years, its participation in global value chains has remained low. It has a small but growing share of trade within GVCs. This share increased from $1.4 \%$ in 1995 to $2.2 \%$ in 2011 (UNCTAD-Eora Database, 2014). Despite this low share, it has a high total level of integration in GVCs compared to other regions, but more for downstream integration than for upstream integration (AfDB et al., 2014). Europe has $40 \%$ of intermediate products integrated into African exports, and Asia 30\%. The share of intra-Saharan Africa trade has changed dramatically from 14.38\% in 1995 to $20.58 \%$ in 2016 with an average value of $15.08 \%$ during this period. This percentage is much lower than intra-European Union trade, which is in the order of $65.87 \%$ and $48.28 \%$ in the NAFTA area (UNCTAD, 2016).

Knowing that regional integration is a priority for development in Africa (AfDB et al., 2017), we remain concerned about the low level observed in SSA and which is justified by traditional theories of international trade. The new theories of the geographical economy and the new international economy reasoning in imperfect competition, in terms of territorialized sectors (Hugon \& de Bandt, 1988) and regional value chains (AfDB et al., 2014; OECD, 2014; Baldwin, 2012; Koopman et al., 2010) are new paradigms to be examined. Indeed, we can see that today, as a result of offshoring and increasing inter-connectivity, the activities that form the value chains of many products and services are increasingly fragmented across the globe and between companies. Various tasks along the production chain can be carried out in remote locations, depending on the respective comparative advantages of different countries and promote their industrial development (AfDB et al., 2013; Cattaneo et al., 2013; OECD, 2013; Gereffi \& Lee, 2012).

Despite their efforts, most African countries have encountered pitfalls in their industrial development. For example, the study by Hossein and Weiss (1999) showed that 7 African countries out of the 16 in its sample experienced deindustrialization during the period 1975-1993. As proof, while from 1980 to 2009, the contribution of manufacturing industries to GDP increased slightly in North Africa, from $12.6 \%$ to $13.6 \%$, it declined in the rest of the continent, where it fell from $16.6 \%$ to $12.7 \%$. This share has also seen a downward trend in sub-Saharan Africa, ranging from $24.94 \%$ in 1995 to $14.37 \%$ in 2012 (World Bank, 2013).

In view of this low level of industrialization in sub-Saharan Africa combined with weak trade integration in this part of Africa and given this new approach to trade based on the popularization of trade in intermediate products, a set of questions emerge: can the countries of sub-Saharan Africa not exploit this international division of the productive process to develop their industries? Does not the exploitation of the specificities of each country leading to complementary activities promote their industrialization? What are the incentives to be implemented by governments for the development of regional value chains conducive to industrialization?

The objective of this article is to show that the exploitation of regional value 
chains in sub-Saharan Africa contributes to the industrialization that is part of one of the five accelerators (called High 5) defined by the African Development Bank to ensure the economic transformation of the continent. To do this, the rest of this reflection consists of the second section which presents the literature review, the methodology of the study is the subject of the third section, in the fourth section will be discussed the results and finally, we will conclude the work in the fifth section by presenting some economic policy implications.

\section{Litterature Review}

The assessment of the effects of international value chains on industrialization requires an understanding of this type of transaction from the point of view of economic theory. Two models have been proposed for this purpose: Feenstra (1996), Feenstra and Hanson (1997) start from the Heckscher-Ohlin framework but divide the production process of a final good or service into a number of activities. These activities are then linked to the location where they can be carried out most efficiently. Grossman and Rossi-Hansberg (2008) present a similar model of commerce but are interested in tasks rather than activities. In this model of task trading, what matters is the nature of the routine tasks, the way in which they are performed and the possibility of codifying them.

One difference between the two models relates to the role of the company. Feenstra and Hanson's model can be interpreted as describing arm's length transactions because it assumes that there is a technology gap between the home and host countries (i.e., it sees the possibility of outsourcing). Grossman and Rossi-Hansberg's model can be interpreted as describing transactions internal to the company because the levels of technology are identical between two locations (i.e., it envisages offshoring).

These two models also have points of convergence in the sense that production is now broken down into several stages and spread over several zones according to their competitive advantages. There is therefore an international fragmentation or decomposition of production processes (Lassudrie-Duchêne, 1982) which refers to the division of the stages of production of a multinational firm (FMN) between different countries. This international fragmentation has given rise to a new form of international trade, intra-firm trade, which refers to the exchange of intermediate and final goods between enterprises of the same structure (between subsidiaries and parent companies, subsidiaries between them, etc.). Today, much of the international trade and exports of a good number of countries are intra-firm in nature.

Finally, the DIPP and intra-firm trade, from a managerial point of view, are nothing more than a further fragmentation of the value chain at the global level. In this sense, FMNs undertake a reorganization of their structure, by splitting the production process, which responds first to strategic and managerial concerns such as competitive pressure, the search for performance, proven in terms of growth and productivity gains (Barba-Navaretti \& Castellani, 2003), or the 
search for efficiency and new comparative advantages (Fontagné \& Zignago, 2007). It is in this context that the global value chain approach was developed successively by Porter (1986), Gereffi et al. (2005).

Baldwin notes that this "new paradigm of globalization" has a number of profound consequences. First, and in line with the Rossi-Hansberg model of task exchange, it is becoming more difficult to predict who the winners and losers will be in the game of globalisation. This affects the extent to which the winners in the globalization process can compensate the losers, which increases uncertainty for workers in general. These effects also increase the difficulty for governments to prepare their people for the effects of globalization, including through training, as well as their ability to convince people to support trade policy. A second consequence is that production is becoming more mobile, as differences in the policies of the various administrations can have a greater impact. Baldwin calls this the "multiplier effect", which echoes Globerman's observation that competition takes place at a more granular level.

Faced with this situation, several works have been carried out and it emerges that any State wishing to take advantage of these GVCs must take a number of measures both internally and externally.

In a study entitled "Global value chains: economic and strategic issues", Globerman (2007) argues that GVCs are essentially business activities at a more granular level, these activities are determined by the same factors that explain the classical theory of trade including the notion of comparative advantage. Thus, we can expect that trade within GVCs will generate the same benefits as that arising from international trade, but with the clarification that this trade is at a finer level of disaggregation and that it includes more services, which should lead to additional trade-related gains. Globerman (2007) points out that increased competition at a finer level of disaggregation requires more granular policies, including improved infrastructure, investment in R\&D and education, and the removal of barriers to trade. All these measures will have beneficial effects within the framework of GVCs.

At the domestic level, the public authorities have several means at their disposal, which are basically similar to those deployed to increase productivity: strengthening competition in product markets to encourage companies to improve their productivity, supporting a dynamic market sector so that new innovative businesses can be created, experimented and grow; investing in public goods that are conducive to improving productivity, such as education, research and infrastructure; and create the necessary framework conditions for productive investment in these areas (AfDB et al., 2013). The objective of development policy is to determine in which value chain the country is best positioned and for which activities the country's offer is the most competitive (Cattaneo \& Miroudot, 2013). Manufacturing assembly operations require efficient logistics. They also require a reliable energy supply and a sufficient supply of workers with the right skills. Once a country has entered a global value chain at the stage of prod- 
uct production, its progression within that chain, or the development of additional product types, requires a range of services, which must be competitive in both price and quality. This is particularly crucial for local small and medium-sized enterprises (SMEs), which need access to a range of services in order to be able to focus on the specific activity within the value chain that is their strong point. Infrastructure needs, skills (AfDB, 2012; UNCTAD, 2013; OECD, 2013) and services are often specific to the value chain.

Trade policy measures are also essential for the integration of countries into industrializing global value chains; Trade liberalization measures can broadly improve the competitiveness of countries in international supply chains. Measures that restrict access to foreign intermediate products and services increase production costs and hinder participation in value chains (OECD et al., 2013). As global value chains tend to accentuate the negative effects of protectionist policies, countries seeking to protect their own production networks may not have access to the trade opportunities that result from globalization (Lesser, 2014).

African countries can benefit from both import and export trade facilitation measures. Reforms of customs and border procedures can reduce transaction costs and contribute to development. For example, in Ethiopia, as a result of these reforms, imports and exports jumped by $200 \%$, and tax revenues increased by more than $51 \%$ (Lesser, 2014). Trade facilitation measures are particularly important to help African SMEs participate in global value chains, as these SMEs often lack sufficient financial and human resources to cope with the complexity of border red tape (Lesser, 2014). Reforms in this area must not depend on an international agreement.

Accelerating regional integration and promoting regional value chains can create opportunities and improve participation in global value chains. In addition, emerging economies' markets and regional value chains are generally characterized by low requirements but can be gradually strengthened. The current low-level conditions for participation in regional and South-South value chains may not provide sufficient social and environmental protection, but they do allow African companies to improve their productive capacities and gradually move up value chains (Evers et al., 2014; Cadot et al., 2012).

Regional trade agreements could contribute to increasing levels of regional integration that remains low. Many trade agreements exist between African countries, but they are often still not applied at border crossings or by the customs administration. Their deepening could expand opportunities within value chains focused on regional production for regional markets or for interconnected regional firms supplying global markets (Bamber et al., 2014).

\section{Methodology of the Study}

\subsection{The Theorical Model}

We start from the approach of Rowthorn and Wells (1987), who propose a 
theoretical model whose industrialization or deindustrialization could be observed without commercial links with the rest of the world. Our specificity is therefore to propose a model in an open economy. The main stylized facts require that the income elasticity of food demand is inelastic, real demand for services increases with national income, and labour productivity is higher in the manufactured (industrial) sector than in the services sector. On the basis of these proposals, it is explained how, in the development phase, there is an increasing importance of industrial production, which leads to a transition to a service economy that foresees the future decline in industrial employment (Rowthorn \& Ramaswamy, 1997).

The model states that the overall product $(Y)$ comes from three sources, namely agriculture $\left(Y_{a}\right)$, industry $\left(Y_{i}\right)$ and services $\left(Y_{s}\right)$ :

$$
Y=Y_{a}+Y_{i}+Y_{s}
$$

Per capita consumption of agricultural products is considered to be fixed. On the other hand, the population is also fixed and equal to $L$, and it is assumed that the economy is in a situation of full employment. As a result of these assumptions, it can be noted that $Y_{a}=b Y \quad(0<b<1)$ and $Y_{s}=c Y \quad(0<c<1)$, that is, $b$ and $c$ are constants.

As far as productivity in each sector is concerned, we assume that it grows at a constant rate over time. Productivity in the agricultural and industrial sectors is equal but higher than in the services sector:

$$
\begin{aligned}
& y_{a}=y^{0} \mathrm{e}^{\lambda \alpha t} \\
& y_{i}=y^{0} \mathrm{e}^{\lambda \alpha t} \\
& y_{s}=y^{0} \mathrm{e}^{\alpha t}
\end{aligned}
$$

$y_{a}, y_{i}$ and $y_{s}$ represents products per head ${ }^{1}, \lambda>1, y^{0}>0$ and $\alpha>0$ are constants. On the basic of these details, the total employment is written:

$$
L=\frac{Y}{y^{0}}\left[c \mathrm{e}^{-\alpha t}+(1-c) \mathrm{e}^{-\lambda \alpha t}\right]
$$

Therefore,

$$
y=\frac{y^{0} \mathrm{e}^{\alpha t}}{c+(1-c) \mathrm{e}^{-\alpha(\lambda-1) t}}=\frac{y_{s}}{c+(1-c) \mathrm{e}^{-\alpha(\lambda-1) t}}
$$

$y=Y / L$ is defined as the total productivity of the economy (in all three sectors).

Due to the fact that $\alpha>0$ and $\lambda>1$, the asymptotic behavior of the relationship (4) results in:

$$
\frac{y}{y_{s}}=\frac{1}{c}
$$

${ }^{1}$ The products per head in each sector are defined as follows: $y_{a}=\frac{Y_{a}}{L_{a}}, \quad y_{i}=\frac{Y_{i}}{L_{i}}$ et $y_{s}=\frac{Y_{s}}{L_{s}}$, with $L_{a}, L_{i}$ and $L_{s}$ employment in sectors, such as $L=L_{a}+L_{i}+L_{s}$. 
This equality is in line with the principle of Baumol et al. (1989) according to which the average rate of productivity growth decreases in line with growth in the services sector. This is an illustration of the theory of asymptotic stagnation because global growth is constrained by what is happening in the dominant economic sector.

By defining $P_{a}=\frac{L_{a}}{L}, P_{i}=\frac{L_{i}}{L}$ and $P_{s}=\frac{L_{s}}{L}$ the relative shares of employment in the agricultural, industrial and service sectors, it can be established that:

$$
\begin{aligned}
& P_{a}=\frac{b}{y^{0}} \mathrm{e}^{-\lambda \alpha t} \\
& P_{s}=\frac{c}{c+(1-c) \mathrm{e}^{-\alpha(\lambda-1) t}}
\end{aligned}
$$

Given that $P_{i}=1-\left(P_{a}+P_{s}\right)$, it follows that:

$$
P_{i}=1-\left[\frac{b}{y^{0}} \mathrm{e}^{-\lambda \alpha t}\right]-\left[\frac{c}{c+(1-c) \mathrm{e}^{-\alpha(\lambda-1) t}}\right]
$$

Thus, when $t$ tends towards infinity $P_{i} \rightarrow 0$, since $P_{a} \rightarrow 0$ and $P_{s} \rightarrow 1$. In other words, the share of agricultural employment tends to cancel out while that of services tends towards 1 . But what about the share of industrial employment?

Let us start from the fact that $P_{i}=1-\left(P_{a}+P_{s}\right)$. The differential of this relation gives

$$
\frac{\mathrm{d} P_{i}}{\mathrm{~d} t}=-\frac{\mathrm{d} P_{a}}{\mathrm{~d} t}-\frac{\mathrm{d} P_{s}}{\mathrm{~d} t}=\lambda \alpha P_{a}-(\lambda-1) \alpha P_{s}\left(1-P_{s}\right)
$$

Thus, $\frac{\mathrm{d} P_{i}}{\mathrm{~d} t}>0$ if and only if $\lambda \alpha P_{a}>(\lambda-1) \alpha P_{s}\left(1-P_{s}\right)$, that is, when the rate of decline of the agricultural labour force is higher than the rate of growth of employment in the service sector. In poor or developing countries, this condition is easily met since $P_{a}$ is high. With this in mind, an increase in the share of industrial employment is expected.

Finally, the share of industry in the real product (industrialization rate) is broken down as follows:

$$
\frac{Y_{i}}{Y}=1-\frac{Y_{s}}{Y}-\frac{Y_{a}}{Y}=1-c-\frac{b}{y^{0}} \mathrm{e}^{-\alpha t} c+(1-c) \mathrm{e}^{-\alpha(\lambda-1) t}
$$

This share grows rapidly in the initial stage of development but converges towards an upper limit over time. In a mature economy, the rate of industrialization stabilizes while employment in the sector tends to decline, due to increasing productivity.

\subsection{The Empirical Model}

The process of industrialization was studied by Hossein and Weiss (1999) in absolute and relative terms. In the absolute version, the analysis of the industrialization process is based on the value-added of the secondary sector, while the rel- 
ative version focuses on the rate of industrialization, i.e. the share of the absolute value of the secondary sector in GDP. Hossein and Weiss (1999) explain industrialization through internal factors such as GDP, urbanization, natural resources, and external factors, including trade openness]. But this approach is limited, as it ignores the influence of certain factors such as physical capital formation, North-South trade and especially South-South trade on industrialization. However, these variables have been used by Rowthorn and Ken Coutts (2004), Brady et al. (2011), Rowthorn and Ramaswamy (1999) to analyze the industrialization process in Europe and Latin America, but also by NgoaTabi and Atangana Ondoa (2013) for Africa. As part of this work, we propose to estimate the effects of intra-Saharan trade on the level of industrialization of these different countries following the international value chain approach with reference to Cattaneo and Miroudot (2013), Azmeh (2013), Hanlin and Kaplinsky (2013), Cattaneo et al. (2013), OECD (2013), Baldwin (2012), Gereffi and Lee (2012), Frederick and Gereffi (2009), Gereffi et al. (2005), Humphrey and Schmitz (2002).

For this purpose, the model is as follows:

$$
\begin{aligned}
I N D_{i t}= & \beta_{0}+\beta_{1} \ln G D P_{i t}+\beta_{2} \ln Y 2_{i t}+\beta_{3} \ln U r b_{i t}+\beta_{4} \ln \operatorname{Scol}_{i t} \\
& +\beta_{5} \ln G F C F_{i t}+\beta_{6} \ln \operatorname{Pop}_{i t}+\beta_{7} \ln D m g_{i t}+\beta_{8} \ln \operatorname{ComExt}_{i t}+\mu_{i t}
\end{aligned}
$$

In the relationship (1), we have on our left the variable explained:

$I N D$ : is the rate of industrialization, $t$ time, $i$ the country. We measure industrialization by three indicators: 1 ) we first use the rate of industrialization, which is the ratio of the value-added of industries to GDP (NgoaTabi \& Atangana Ondoa, 2013; Hossein \& Weiss, 1999); 2) secondly, we retain manufacturing value-added, which captures the ability to transform natural resources into final goods (Dong et al., 2011); 3) finally, we use the ratio of industrial employment to total employment, which explains how intermediate goods are processed, and describes the quality of the labour force needed (Gui-Diby \& Renard, 2015; Kaya, 2010);

$G D P$ : is the real gross domestic product per capita in level and squared, with a view to testing the U-shaped relationship between GDP and industrialization or deindustrialization postulated by Clark (1957);

Urb: the level of urbanization in the country, approximated by the proportion of the population living in urban areas;

Scol: secondary school enrolment;

GFCF: gross fixed capital formation as a percentage of GDP at constant prices. These are all explanatory variables that will make it possible to assess the influence of modernity on industrialization.

Indeed, the output of manufacturing goods is generally capital-intensive and any change in the investment rate affects the demand for manufacturing products (Rowthorn \& Ken Coutts, 2004). It can be observed with Brady et al. (2011) that the process of industrialization requires a minimum level of modernity that can be approximated by factors such as urbanization, schooling and the forma- 
tion of physical capital. In addition, the variable Pop: denotes total population will make it possible to assess the influence of the local market on the rate of industrialization.

Dmg. refers to the average duration of the war in five years as an indicator of political instability;

ComExt. refers to trade between each country in sub-Saharan Africa and the rest of the countries in that subregion. Since it is a question for us to understand this trade in terms of integration into international value chains, we retain:

- Downstream integration (measured by the share of raw materials in the exports of each country of sub-Saharan Africa to the others). Downstream integration is the share of a country's value-added exports that is reflected in the exports of other countries. We look at the point of view of a country's exports around the world, in particular the products that go into the production of other countries' exports (De Bakker \& Miroudot, 2013; OECD, 2013).

- and upstream integration (captured by the share of intermediate products in the imports of each sub-Saharan African country from the others). Upstream integration is the share of foreign value-added in a country's exports. We look at a country's exports and study the importance of foreign factors of production in local production (De Baker \& Miroudot, 2013; OECD, 2013).

The combination of upstream and downstream integration provides an indication of the full participation of a sub-Saharan African country in sub-Saharan value chains. Both concepts are expressed as a percentage of each country's gross exports. Although participation in these value chains is broadly similar for all these countries, the larger economies show lower figures because they rely less on production for sub-regional trade, while small open economies are more integrated into regional production networks. Small open economies, such as Lesotho or Mauritius, acquire more production goods abroad and produce more goods used in these value chains than large economies, such as Nigeria or South Africa, where a larger part of the value chain is located within the country. Nevertheless, total participation in THEC Is less determined by the size of the country than upstream integration (foreign value-added content of exports), as it is also concerned with the use of production goods in third economies (OECD, 2013).

The $\beta$ are parameters to be estimated, and $\mu$ represents the error term. All other variables are expressed in natural logarithms. It follows that the estimated coefficients of these variables will be directly interpreted as elasticities (Table 1).

An analysis of the coefficient of variation (CV) shows that apart from the variables urban population and openness ratio to other partners that have a high dispersion, the other variables have a low dispersion. This strong dispersion of the two variables confirms their volatile nature, which may be attributable to a strong rural exodus due to the search for well-being in urban centres and the availability of raw materials; but also internal unrest in countries and their heterogeneous nature. 
Table 1. Descriptive statistics.

\begin{tabular}{|c|c|c|c|c|c|c|}
\hline Variables & Obs & Average & $\begin{array}{l}\text { Standard } \\
\text { deviation }\end{array}$ & $\mathrm{CV}$ & Min & $\operatorname{Max}$ \\
\hline Value added to GPD & 794 & 26.81 & 15.60 & 0.58 & 1.88 & 95.70768 \\
\hline Gross Domestic Product & 855 & 8661.878 & $17,768.89$ & 0.002 & 96.9 & $176,644.6$ \\
\hline Urban Population & 855 & $4,281,333$ & $8,764,468$ & 2.04 & $35,498.87$ & $7.89 \mathrm{e}+07$ \\
\hline $\begin{array}{l}\text { Gross Fixed Capital } \\
\text { formation (\% GDP) }\end{array}$ & 855 & 0.49 & 0.17 & 0.34 & 0.017 & 4.310608 \\
\hline Schooling (\% secondary) & 810 & 59.64 & 24.98 & 0.42 & 23.64 & 175.8505 \\
\hline Total Population & 855 & $1.64 \mathrm{e}+07$ & $3.00 \mathrm{e}+07$ & 1.82 & $512,575.8$ & $1.93 e+08$ \\
\hline $\begin{array}{l}\text { Downstream integration } \\
(\text { sub region SSA })\end{array}$ & 840 & 19.14 & 9.59 & 0.51 & 5.10 & 26.56881 \\
\hline $\begin{array}{l}\text { Upstream Integration (sub } \\
\text { region SSA) }\end{array}$ & 850 & 21.15 & 7.12 & 0.33 & 9.43 & 32.51 \\
\hline $\begin{array}{c}\text { Downstream integration } \\
\text { (with others) }\end{array}$ & 851 & 30.14 & 63.59 & 2.11 & 23.10 & 95.56881 \\
\hline $\begin{array}{l}\text { Upstream integration (with } \\
\text { others) }\end{array}$ & 855 & 36.15 & 9.12 & 0.25 & 9.43 & 54.51 \\
\hline
\end{tabular}

Source: authors from UNCTAD database, UNCTAD stat 2014, WDI, IMF.

Data source

The data used in this work cover the period 1995-2015. They come from the bases of international organizations or research centers. The information on the variables explained is taken from UNCTADSTAT in UNCTAD and WDI in The World Bank.

Estimation Technique

Since our study concerns the countries of sub-Saharan Africa that are observed over a period of 21 years, we find that both the inter-individual and inter-temporal dimensions are considered and the appropriate model here is the panel regression. But the validity of a model in panel data is conditional on certain diagnostic tests, one of the most important of which is the stationarity test. There is a multitude of approaches to testing for the presence of unit roots in panel data. However, the use of either approach depends on the nature of the data. In our context where the sample is not rigorously censored, the most appropriate test is the Fisher test which knows specifications under four laws, namely the inverse Chi-two distribution, the inverse normal distribution, the inverse logit and the modified inverse logit.

The preliminary results of these tests can pave the way for conventional estimation methods, including ordinary least squares on stacked or cross-section data, linear panels (fixed effects versus random effects). However, these methods remain silent as to the control of endogeneity bias, which remains highly likely since the causality between industrialization and each of our explanatory va- 
riables can work in both directions (Lee \& Chang, 2009; Cynthia \& Liscow, 2013), which justifies the specification of our dynamic panel model.

Indeed, in a dynamic panel model, the effects specific to unobservable countries are correlated with the delayed dependent variable, which provides inconsistent estimators. Using the delayed values of the primary difference of the endogenous variable as instruments, Holtz-Eakin, Newey and Rosen (1988) and Arellano and Bond (1991) developed a consistent estimator, called the difference GMM estimator. However, Arellano and Bover (1995), then Blundell and Bond (1998) demonstrated that when the dependent variable is persistent over time, the delayed values are very bad instruments. By using additional moment conditions, these authors manage to develop a more robust alternative estimator called a GMM estimator in system.

\section{Study Results}

Table 2 presents the results of the estimates with the GMM in a system of two specifications for the entire sample. Model 1 corresponds to the basic model where industrialization is explained by the traditional variables namely; domestic GDP, educational attainment, gross fixed capital formation and our variables of interest: upstream integration and downstream integration. In Model 2, other variables are taken into account, including the urban population and the total population, the share of natural resources in exports and intermediate products in their imports from other partners.

Both specifications are globally significant. Indeed, the null hypothesis of Fisher's global significance tests is rejected (p-value is equal to 0.000). In addition, Sargan's over-identification test confirms the validity of the variables delayed in level and difference as instruments used in all our specifications. In addition, arellano and Bond's second-order autocorrelation test does not reject the hypothesis of no second-order autocorrelation of our specifications.

In general, it emerges from the results, contained in this table below, that the variables of model 1 have the expected signs with, however, variable statistical significance. Indeed, the significance of the coefficient of the delayed dependent variable (ln VA/GDP L1) reveals that the level of industrialization of the previous period has a significant positive effect on the level of the following period. The estimated coefficient (in our first model) indicates that an increase in this initial level of $10 \%$ leads to an increase of $7.5 \%$ for the following period taking into account the influence of the other variables. Similarly, intra-regional trade as measured by the ratio of natural resource exports has a positive effect on industrialization with a significance of 10 percent; an increase in this opening of $10 \%$ leads to an improvement in industrialization of $0.04 \%$. Indeed, the import of intermediate products from other countries of sub-Saharan Africa is a source of industrialization in these countries. Similarly, variables such as gross fixed capital formation and educational attainment have a positive impact on the level of industrialization. 
Table 2. Results of estimates with the GMM in system of the industrialization equation of the SSA countries.

\begin{tabular}{|c|c|c|}
\hline Variables & Model 1 & Model 2 \\
\hline Ln added value/gdp L1. & $0.754\left(21.13^{\star * *}\right)$ & $0.767\left(22.80^{* * *}\right)$ \\
\hline Ln gross domestic product & $0.075\left(4.04^{* * *}\right)$ & $0.078\left(2.11^{\star}\right)$ \\
\hline Ln gross domestic product & & $0.0141(0.76)$ \\
\hline Ln gross fixed capital formation & $0.011\left(1.86^{*}\right)$ & $0.182\left(2.12^{\star}\right)$ \\
\hline Ln schooling & $0.013\left(2.31^{\star *}\right)$ & $0.488\left(2.51^{\star}\right)$ \\
\hline Ln urban population & & $0.031(0.90)$ \\
\hline Ln total population & & $0.301(1.45)$ \\
\hline Ln dowvstream integration (sub regional) & $0.004\left(1.39^{*}\right)$ & $0.012\left(1.67^{\star}\right)$ \\
\hline Ln upstream integration (sub regional) & & $0.015\left(0.62^{\star \star}\right)$ \\
\hline Ln downstream integration (to outside) & $0.014\left(0.60^{\star *}\right)$ & $0.016\left(1.79^{\star}\right)$ \\
\hline Ln upstream integration (to outside) & & $0.026\left(0.31^{\star}\right)$ \\
\hline Constancy & $1.168\left(3.02^{\star}\right)$ & $0.911\left(2.26^{\star}\right)$ \\
\hline Number of observations & 691 & 633 \\
\hline Statistic F- (p-value) Prob $>$ F & 0.000 & 0.000 \\
\hline Test autocor.1 Arellano-bond & 0.000 & 0.000 \\
\hline Test autocor.2 Arellano-bond & 0.212 & 0.117 \\
\hline Test on identification of Sargan & 0.000 & 48.25 \\
\hline Probability on test of Sargan & 0.542 & 0.867 \\
\hline
\end{tabular}

The values in parentheses are $z$-stat and ${ }^{\star} 10 \%$ significance; ${ }^{\star} 5 \%$ significance; $1 \%$ significance. Source: authors based on our own calculations.

In the second model, we find that there is no major change in the values of the coefficients taken into account in the first model. Similarly, the significance is almost unchanged. It is therefore a question for us of observing the effects of the new variables on industrialization. From the outset, we note that the values of the coefficients of the variables taken into account are in line with the theory with, however, various significances.

The coefficients of our variables of interest that concern international value chains, namely the proportion of natural resources in intra-regional exports and the proportions of intermediate consumption in imports from the same subregion, have signs in line with economic intuition. In concrete terms, the sign of the coefficient of the variable "intermediate consumption (\% M coming from the SA)" is positive and significant at $5 \%$. This means that imports of intermediate products from the sub-region have a positive impact on the level of industrialization. A $10 \%$ increase in imports of these products improves the industrialization of sub-Saharan African countries by $1.5 \%$.

Similarly, the coefficient of the variable "import of intermediate consump- 
tion" from the other partners has a positive and significant sign at $10 \%$. This means that this variable has a positive impact on the level of industrialization in sub-Saharan Africa. More specifically, a 10\% increase in imports of this intermediate consumption leads to a $0.26 \%$ improvement in the level of industrialization of the countries of sub-Saharan Africa.

\section{Conclusion}

The objective of this article was to highlight the main effects of integration into regional value chains on the industrialization of sub-Saharan Africa. To this end, after a review of the literature, we carried out an econometric analysis based on data from the World Bank as well as those from UNCTAD for the period 19952015. The estimates made from GMM in system have led to the following results: 1) sub-regional trade participates in the industrialization of this sub-region; 2) Upstream integration contributes more to industrialization than downstream integration; 3) trade with other partners contributes more to the industrialization of the subregion than intra-regional trade. In these circumstances, African leaders must promote not only trade among African countries but above all encourage trade in intermediate products. For this to be effective, actions must be directed towards improving the level of infrastructure and the training of young Africans.

\section{Conflicts of Interest}

The authors declare no conflicts of interest regarding the publication of this paper.

\section{References}

AfDB (African Development Bank) (2012). Étude comparative des politiques d'exportation de l'Égypte, du Maroc, de la Tunisie et de la Corée du Sud. Banque africaine de développement.

AfDB (African Development Bank), OECD (Organisation for Economic Co-Operation and Development), UNDP (United Nations Development Programme), \& UNCTAD (United Nations Conference on Trade and Development) (2013). African Economic Outlook. OECD Publishing.

AfDB (African Development Bank), OECD (Organisation for Economic Co-Operation and Development), UNDP (United Nations Development Programme), \& UNCTAD (United Nations Conference on Trade and Development) (2014). African Economic Outlook. OECD Publishing.

AfDB (African Development Bank), OECD (Organisation for Economic Co-Operation and Development), UNDP (United Nations Development Programme), \& UNCTAD (United Nations Conference on Trade and Development) (2017). African Economic Outlook. OECD Publishing. https://doi.org/10.2307/2297968

Arellano, M., \& Bond, S. R. (1991). Some Tests of Specification for Panel Data: Monte Carlo Evidence and an Application to Employment Equations. The Review of Economic Studies, 58, 277-297. https://doi.org/10.2307/2297968

Arellano, M., \& Bover, O. (1995). Another Look at the Instrumental Variable Estimation of Error-Components Models. Journal of Econometrics, 68, 29-51.

https://doi.org/10.1016/0304-4076(94)01642-D 
Azmeh, C. (2013). Asian Capital and Labour Flows into the Apparel Industry of Jordan and Egypt: The Integration of the Qualifying Industrial Zones (QIZs) of Egypt and Jordan into Apparel Global Production Networks. Ph.D. Thesis, Université of Manchester.

Baldwin, R. (2012). Global Supply Chains: Why They Emerged, Why They Matter, and Where They Are Going. Discussion Paper No. 9103, Centre for Economic Policy Research, London. https://papers.ssrn.com/sol3/papers.cfm?abstract_id=2153484

Bamber, C., Elezi, E., Bamber, D., \& Sharp, J. (2014). A Critical Review of ISO Manage-ment Systems Certification in the UK Agricultural Sector. 9th Mibes International Conference, 30 May-1 June 2014.

Barba-Navaretti, G., \& Castellani, D. (2003). Investments Abroad and Performance at Home. Evidence from Italian Multinationals. Development Studies Working Papers No. 180, Centro Studi Luca d'Agliano.

Baumol, W. J., Blackman, S. A. B., \& Wolff, E. N. (1989). Productivity and American Leadership: The Long View. MIT Press.

Blundell, R., \& Bond, S. (1998). Initial Conditions and Moment Restrictions in Dynamic Panel Data Models. Journal of Econometrics, 87, 115-143. https://doi.org/10.1016/S0304-4076(98)00009-8

Brady, D., Kaya, Y., \& Gereffi, G. (2011). Stagnating Industrial Employment in Latin America. World and Occupations, 38, 179-220. https://doi.org/10.1177/0730888410387987

Cadot, O., Malouche, M., \& Sáez, S. (2012). Streamlining Non-Tariff Measures: A Toolkit for Policy Makers. World Bank. https://doi.org/10.1596/978-0-8213-9510-3

Cattaneo, O., \& Miroudot, S. (2013). From Global Value Chains to Global Development Chains: An Analysis of Recent Changes in Trade Patterns and Development Paradigms. Policy Research Working Paper No. 6406, World Bank. https://doi.org/10.1596/1813-9450-6406

Cattaneo, O., Gereffi, G., Miroudot, S., \& Taglioni, D. (2013). Joining, Upgrading and Being Competitive in Global Value Chains: A Strategic Framework. World Bank. https://doi.org/10.1596/1813-9450-6406

Clark, C. (1957). The Conditions of Economic Progress. Macmillan.

Cynthia, L., \& Liscow, Z. (2013). Endogeneity in the Environnemental Kuznts Curcve: An Instrumntal Variable Approch. American Journal of Agriculture Economics, Agricultural and Applied Economics Association, 95, 268-274. https://doi.org/10.1093/ajae/aas050

De Backer, K., \& Miroudot, S. (2013). Mapping Global Value Chains. Working Paper No. 1677, European Central Bank. https://doi.org/10.2139/ssrn.2436411

Dong, X., Song, S., \& Zhu, H. (2011). Industrial Structure and Economic FluctuationEvidence from China. The Social Science Journal, 48, 468-477. https://doi.org/10.1016/j.soscij.2011.05.002

Evers, B. et al. (2014). Global and Regional Supermarkets: Implications for Producers and Workers in Kenyan and Ugandan Horticulture. Working Paper No. 39, Capturing the Gains.

Feenstra, R. (1996). Integration of Trade and Desintegration of Production in Global Economy. Journal of Economic Perspectives, 12, 31-50. https://doi.org/10.1257/jep.12.4.31

Feenstra, R. C., \& Hanson, G. H. (1997). Foreign Direct Investment and Relative Wages: Evidence from Mexico's Maquiladoras. Journal of International Economics, 42, 371-393. 
https://doi.org/10.1016/S0022-1996(96)01475-4

Frederick, S., \& Gereffi, G. (2009). Review and Analysis of Protectionist Actions in the Textile and Strategic Framework. Policy Research Working Paper No. 6406, World Bank.

Gereffi, G., \& Lee, J. (2012). Why the World Suddenly Cares About Global Supply Chains. Journal of Supply Chain Management, 48, 24-32. https://doi.org/10.1111/j.1745-493X.2012.03271.x

Gereffi, G., Humphrey, J., \& Sturgeon, T. (2005). The Governance of Global Value Chains. Review of International Political Economy, 12, 78-104. https://doi.org/10.1080/09692290500049805

Globerman, S. (2007). Global Value Chains: Economic and Strategic Issues. Western Washington University and Simon Fraser University.

Grossman, G., \& Rossi-Hansberg, E. (2008). Trading Task: A Simple Theory of Offshoring. American Economic Review, 98, 1978-1997. https://doi.org/10.1257/aer.98.5.1978

Gui-Diby, S. L., \& Renard, M.-F. (2015). Foreign Direct Investment Inflows and the Industrialization of African Countries. World Development, 74, 43-57. https://doi.org/10.1016/j.worlddev.2015.04.005

Hanlin, C. J., R. E., \& Kaplinsky, R. (2013). Inclusive Development: An Architecture for Policy Development. IKD Working Paper 65, The Open University.

Holtz-Eakin, D., Newey, W., \& Rosen, H. (1988). Estimating Vector Autoregression with Panel Data. Econometrica, 56, 1371-1395. https://doi.org/10.2307/1913103

Hossein, J., \& Weiss, J. (1999). Deindustrialisation in Sub-Saharan Africa: Myth or Crisis? Journal of African Economics, 19, 24-43. https://doi.org/10.1093/jae/9.1.24

Hugon, P., \& de Bandt, J. P. J. (1988). Jacques de Bandt et Philippe Hugon (dir.), Les tiers nations en mal d'industrie. Revue Tiers Monde, Programme National Persée, 29, 1035-1036.

Humphrey, J., \& Schmitz, H. (2002). How Does Insertion in Global Value Chains Affect Upgrading in Industrial Clusters? Regional Studies, 36, 1017-1027. https://doi.org/10.1080/0034340022000022198

Kaya, Y. (2010). Globalization and Industrialization in 64 Developing Countries, 1980-2003. Social Forces, 88, 1153-1182. https://doi.org/10.1353/sof.0.0300

Koopman, R., Wang, Z., \& Wei, S.-J. (2010). Tracing Value-Added and Double Counting in Gross Exports. National Bureau of Economic Research.

Lassudrie-Duchêne, B. (1982). L'échange international avec segmentation des produits: Une approche par la théorie classique des coûts compares. In B. Lassudrie-Duchêne, \& J. L. Reiffers dir., Le protectionnisme: Croissance, limites, voies alternatives, Economica.

Lee, C. C., \& Chang, C. P. (2009). Stochastic Convergence of Per Capita Carbon Dioxide Emission and Multiple Structural Breaks in OECD Countries. Economic Modelling, 26, 1375-1381. https://doi.org/10.1016/j.econmod.2009.07.003

Lesser, C. (2014). Implications of Global Value Chains for Trade Policy in Africa: A Desk Study. Reference Document.

NgoaTabi, H., \& Atangana Ondoa, H. (2013). L'incidence du commerce Nord-Sud et du commerce Sud-Sud sur l'industrialisation en Afrique. BAD, Conférence économique africaine sur Intégration régionale en Afrique.

OECD (Organisation for Economic Co-Operation and Development) (2013). Interconnected Economies: How to Leverage Global Value Chains. OECD Publication.

OECD (Organisation for Economic Co-Operation and Development) (2014). Économies interconnectées: Comment tirer parti des chaînes de valeur mondiales. Publication de l'OCDE. 
OECD (Organisation for Economic Co-Operation and Development), WTO (World Trade Organization), \& UNCTAD (United Nations Conference on Trade and Development) (2013). Implications of Global Value Chains for Trade, Investment, Develop ment and Jobs. Report on the Implications of Global Value Chains for Trade, Investment, Development and Employment Prepared for the G-20 Summit in St. Petersburg, OECD, World Trade Organization and United Nations Conference on Trade and Development.

Porter, M. (1986). L'avantage concurrentiel, comment devancer ses concurrents et maintenir son avance. InterEditions, $647 \mathrm{p}$.

Rowthorn, R. E., \& Coutts, K. (2004). De-Industrialisation and the Balance of Payments in Advanced Economies. Cambridge Journal of Economics, 28, 767-790.

https://doi.org/10.1093/cje/beh034

Rowthorn, R. E., \& Ramaswamy, R. (1997). Deindustrialization: Causes and Implications. Working Paper No. 97/42, International Monetary Fund (IMF). https://doi.org/10.2139/ssrn.882291

Rowthorn, R. E., \& Ramaswamy, R. (1999). Growth, trade and deindustrialization. IMF Staff Papers, 46, 18-41. https://doi.org/10.2139/ssrn.882328

Rowthorn, R., \& Wells, J. (1987). Deindustrialization and Foreign Trade. Cambridge University Press.

Ruta, M., \& Saito, M. (2014, March). Value Chains. Finance \& Development, 51, 52-55.

UNCTAD (United Nations Conference on Trade and Development) (2013). Global Value Chains: Investment and Trade for Development. In World Investment Report 2013 (121-202). United Nations. https://doi.org/10.18356/f045c54c-en

UNCTAD (United Nations Conference on Trade and Development) (2019). Trade and Development Report 2019_Financing a Global Green New Deal. United Nations Conference on Trade and Development, Geneva.

UNCTAD-Eora Database (2014). Transnational Corporations (Vol. 26). United Nations.

World Bank (2013). Global Value Chains, Economic Upgrading, and Gender. Case Studies of the Horticulture, Tourism, and Call Center Industries. Poverty Reduction and Economic Management Network, World Bank.

Zignago, F. L. (2007). A Re-Valuation of the Impact of Regional Agreements on Trade Patterns. Economie International, No. 109, 31-51.

https://doi.org/10.3917/ecoi.109.0031 